\title{
STEERING FROM BISMARCK TO BEVERIDGE: THE FRENCH EXPERIENCE
}

\section{A trajetória de Bismarck a Beveridge: a experiência francesa \\ Dirección de Bismarck para Beveridge: la experiencia francesa}

\author{
Philippe Mossé
}

Laboratoire dĖconomie et de Sociologie du Travail - LEST - Aix Marseille Université - Marseille - France

\begin{abstract}
Objective: To describe the roots of the French Health Care System. Data synthesis: Actually, three dynamics are hidden behind the word crisis. The first dynamic was already there from the start, while the second is the result of an internal dynamic and a third dynamic can be seen as the consequence of external causes. The main recent policies are made of a mix of constraints and incentives. Most of them improve the governance of the health care system. Adaptive as well as innovative, a pragmatic attitude has been applied through compromises. Four features of which can be found: To improve the division of labor amid professionals; to move towards Beveridge like Welfare State model, giving to the central State more power; to enhance expertise through Evidence Based Medicine; to open the internal and external frontiers of the health care system. Conclusion: Those changes were mainly pulled by the moving context rather than pushed by an ideology. Therefore, since its birth, the French health care system evolves more on a muddling through like move than according to a plan given in advance. This happened to be a rather good way to avoid the worst: marketization.
\end{abstract}

Descriptors: Health; Care; Administrative Personnel.

\section{RESUMO}

Objetivo: Descrever as raízes do sistema francês de saúde. Síntese dos dados: Na verdade, três dinâmicas estão escondidas por trás da palavra crise. A primeira dinâmica já existia desde o início, enquanto a segunda é o resultado de uma dinâmica interna e uma terceira dinâmica pode ser vista como consequência de causas externas. As principais políticas recentes são feitas de uma mistura de restrições e incentivos. A maioria delas melhora a governança do sistema de saúde. Adaptativa e inovadora, uma atitude pragmática tem sido aplicada através de acordos. Quatro características podem ser encontradas: melhorar a divisão do trabalho entre profissionais; avançar para Beveridge como modelo de Estado de Bem-estar Social, dando mais poder ao Estado central; aperfeiçoar a proficiência através da Medicina Baseada em Evidências; abrir as fronteiras internas e externas do sistema de saúde. Conclusão: Essas mudanças foram principalmente puxadas pelo contexto em movimento, em vez de impulsionadas por uma ideologia. Portanto, desde seu nascimento, o sistema de saúde francês evolui mais de forma improvisada do que segundo um planejamento prévio. Isso se revelou uma boa maneira de se evitar o pior: a mercantilização.

Descritores: Saúde; Cuidado; Pessoal Administrativo.

\section{RESUMEN}

Objetivo: Describir los origines del Sistema de Cuidado de Salud Francés. Síntesis de los datos: En realidad tres dinámicas se esconden detrás de la crisis mundial. La primera dinámica ya estaba allí desde el principio mientras la segunda resulta de una dinámica interna y la tercera dinámica se puede ver como la consecuencia de causas externas. Las principales políticas recientes son hechas de una mescla de limitaciones e incentivos. La mayoría mejora el gobierno del sistema de cuidado de salud. Adaptativo e innovador, una actitud pragmática ha sido aplicada a través de acuerdos. Se pudo encontrar cuatro características: mejorar la división de trabajo entre los profesionales; mover hacia Beveridge como el modelo de Estado de Bienestar dando más poder al estado central; mejorar la experiencia hacia la Medicina Basada en Evidencia y abrir las fronteras internas y externas del sistema de cuidado de salud. Conclusión: Aquellos cambios fueron tirados principalmente por el contexto de mudanza más que empujado por una ideología. Por lo tanto, desde su nacimiento el sistema de cuidado de salud Francés evoluciona más en arreglarse que de acuerdo a un plan dado con antelación. Eso se dio para ser la mejor manera de evitar lo peor: la marketización.

Descriptors: Salud; Cuidado; Personal Administrativo.

Este artigo foi selecionado, corrigido e aprovado pela Comissão Científica do Fórum Internacional de Sistemas Universais de Saúde, seguindo suas normas e formatação. 


\section{INTRODUCTION}

The French health care system is largely based on a national health insurance (NHI) system which is a part of a welfare state à la française named Sécurité Sociale. The principles of this system were set out right after the Second World War (WW II). Although its explicit objectives were from the beginning to go toward a kind of another of universal coverage, the actual roots were bismarckian.

As a result the whole welfare system was focused on labor. Most of the budget came from wages and a turnover was organized amid employers and employees unions as for to run the $\mathrm{NHI}$ along with the unemployment benefits or the pension system. However, since this foundation time, many changes have occurred; some of them pushed by internal constraints, others pulled by external conditions. These changes cannot be understood without knowing some actual features of the original system. In effect, a reform cannot be successful if it does not take into account what has been historically and socially built before it became necessary.

Therefore, this article will first describe the roots of the French health care system, then it will take a look at the main changes and reforms aiming at not only preserve but somehow improve the system.

\section{DATA SYNTHESIS}

\section{Good willing foundations may built long lasting problems}

Created in 1946, by the Conseil national de la Résistance, the first step of the French welfare state was a political and social tool to put together a divided French population right after the WW II. That is the main reason why the explicit objective was to go quickly forward a Universal Coverage in order to avoid any kind of discrimination.

However, and at the same time, it was necessary to involved civil society while protecting the $\mathrm{NHI}$ from the political game. Therefore, far away from the Beveridge philosophy ${ }^{(1)}$, the model implemented since the 1950's in France was close to the Bismarkian one.

In fact when it comes to define welfare state models many typologies are available ${ }^{(2,3)}$. However the simplest and, from a socio-economic point of view, the most accurate is the one opposing Beveridge to Bismarck ${ }^{(4)}$. The main difference lies on the role played by the administration and the State. In the Beveridge system it is the key actor financing, ruling, regulating, organizing and governing. In the Bismarkian the State acts mainly as a referee and the main actors are the Unions (either employees or employers).

\section{A weak and costly paritarism}

In this model, most if not all of the resources come from wages and not from general taxes. At this time, the most powerful sector was the industrial one and the reconstruction of the French economy was the main goal. Following this industrial logic, the governance has been given to the Unions. Since then, under the name of paritarism, Unions are supposed to organize a turn over giving alternatively the hand to employees or employers Unions.

Here, with those roots, came the first problem. In fact, and unfortunately, governance problems aroused quite quickly as France is not Germany. Meaning that the co-gestion philosophy, which is an absolute necessity for a Bismarckian-like NHI, is not present in the French Unions culture. On the contrary, the French Unions were and are still profoundly divided along ideological lines. As a result, they are historically much more in competition than ready to work hand in hand. Besides, from the 1950 and up to now, the French capitalist (Le grand patronat) gives few place to the employees Unions.

This situation undermined the power of the regulation system based on equal representation between employees and employers. As a result the election process (whether at the local or national levels) has been blocked for years. However, this mechanism has also had positive effects, especially since it has protected the system as a whole from the private insurers wanting to enter the market.

In the Bismarckian model, the State and the administration are not supposed to play any role except to give the main lines of the system and controlling its good functioning. But, in the French $\mathrm{NHI}$ the State was more and more involved to correct this Unions weakness. For years, its main role was to fill the structural NHI deficit and/or to help some specific segments of the system such as hospitals.

For instance, in 1958, a law created the University hospitals in order to boost the medical research and to attract the best physicians that would have been tempted to enter the private sector, but almost nothing was done to control the costs. 
As the result, the public health care expenses went higher and higher. However, this was not so much a problem in a time when health was first seen as an investment in human capital and not yet only as a burden. Furthermore, the hospital sector and, beyond, the whole health care delivery system, were explicitly seen as a crucial feature of the economic growth as well as of the needed social development. Actually, from an economic as from a public health point of view, this period, say from 1950 to 1980, was a big success. The quality of care jumped, access to insurance and care was also regularly increasing and the French people were proud of their $\mathrm{NHI}$ that went from $5 \%$ in the 1960 to more than $10 \%$ in the early 1980's.

From a macroeconomic point of view, this era has been called trente glorieuses in order to point the economic and social growth almost the whole western world knew. As a result, at the end of the XXth century, the French health care system have a lot of qualities, mainly due to the very high skills and technicity of its professional.

However, from a regulation point of view, the landscape is less glorious as, along with this development went or persisted a lot of inequalities. Two main sources of this structural inequality are still there today.

The first one is the variety of Health Insurance Plans themselves and the fact that they all make a distinction between the insured (generally the bread winners) and their dependents. The National Sickness Fund (CNAMTS) is the largest insurer and operates under what is called the General Social Security Scheme. It covers all workers and pensioners, as well as the unemployed and their dependents, amounting in all to about $84 \%$ of the population. There are two other important health insurance schemes: the agricultural fund (MSA) and the fund for the selfemployed (CANAM). In addition more than fifteen specific funds cover workers in specialized occupations and their dependents(5). Among others, and for historical reasons, workers of the public national railways of the mining industry or of religious communities have their own insurance scheme.

Furthermore complementary health insurance, which is voluntary and provided by private non for profit insurance companies (Mutuelles) has expanded involving about $85 \%$ of the population. They mainly cover co-payment on a third-party payment scheme, but those schemes may highly differ from a contract to another.

The second reason for existing and persisting inequalities is due to the total freedom patients and physicians have. This feature is also a Bismarkian one as no constraint was established to rationalize health care neither on the supply side nor on the demand one.

Under the name of libre choix, this original feature means that patients have complete freedom to choose their health providers. In effect, one of the main characteristic of the French system is the fact that it gives free access to health care, making no distinction between primary and secondary care. Patients who need health care are free to choose which physician they consult and have also been allowed to refer themselves to specialists. They could choose between public and private hospitals and between outpatient and hospital treatment.

Indeed, a recent reform on Health Insurance aimed at change the landscape. By July 2005, all those benefiting in France from health insurance coverage must choose their main physician (médecin traitant). As a result, it will cost more to consult a specialist directly, without being referred by this preferred doctor. However, the new rules are still flexible. For instance, this so-called gate keeper, can be either a specialist and there are no geographical constraints. Besides the price and cost differences are rather low. Asa result, the incentives are really weak.

Moreover, freedom also means that physicians are free to choose their place of work and their type of practice. They mainly choose to settle themselves in area with already a high density. It sometimes happens of course that in some rural and mountainous areas and in some medical specialties, medical resources are relatively scarce. This also increases inequalities among citizens. The reason of this inequality is but an economic one as the competition between physicians does not exist except a kind of monopolistic one. It is feed by information asymmetry and the universal phenomenon health economists name the supplier-induced demand ${ }^{(6)}$. As a result, the internal division of the health care system increased, due to hyper-specialization and lack of public (comprehensive, as a example) health policy.

Furthermore, the public-private mix in the health care supply sustains the principle of pluralism: ambulatory care is mainly private and is financed on a fee for service basis, whereas the public sector is mainly responsible for hospital care, since it accounts for two-thirds of the hospital beds. As a result of this poor regulation, the French health care system supports a large relative number of practicing physicians per capita, amounting to 340 per 100 000. The number of physicians more than doubled since the 1980's. The greatest increase has occurred among specialists, since the 1990's, they are more numerous.

All those internal dynamics contribute to increase the cost of health care. Therefore, successive French governments have been attempting years to implement a variety of cost-containment initiatives, most of which have been limited and, therefore, unsuccessful. 


\section{Controlling costs: a trivial pursuit}

Actually, up to the end of the 1970s, the main goal of health policy planning was to sustain general economic growth. Besides, from a macroeconomic perspective, growth was a good way not to choise or establish priorities and therefore to prevent conflict inside the system; at this time wasting money was possible. In this Fordist system, every health policy was expected to mediate investment in human capital. Policies of this kind were costly as they inflated the demand and generated a huge public deficit; but, at this time, nobody gave real attention.

The landscape changed in 1983 (second socialist government). The Government's Keynesian Policy failed in the end to boost the economy. The emerging globalization made difficult the Keynesian and Fordist policy that was the dominating ones during more than forty years.

Through several adaptations and reforms, to address the new economic context while keeping the main features of the health care system, the administration and the political sphere aim at playing a stronger role inside the $\mathrm{NHI}$ itself. To this purpose, two significant measures were taken in the early 1990.

The first one adresses the financial resources. Economic crisis and, mainly, the high level of unemployment made impossible to draw $\mathrm{NHI}$ resources only from the wages and payrolls. New resources were to be found; taxes will be the solution as they are paid by almost all citizens and not only by the workers. This was one of the first step toward a Beveridge like model and will, soon as latter legitimize the increase role of the Stats, while weakening even more the Unions power of decision.

Since 1996, the earmarked General Social Tax (CSG) levied on income at a rate of $5.25 \%$ has replaced most of the previous employees contributions to the social health insurance funds. Year after year, this rate will be constantly increased. The CGS is now one of the main sources of national health insurance funding. Furthermore, a special fund, was also created in order to manage the new social debt repayment tax. A socialist government kept this tax, although the Socialist Party was against its creation.

The current Macron' Government, elected in May 2017 is committed to pursue this process of substituting social contributions for the General Social Tax. Actually, as it is applied to revenues of most kinds including pensions, property rental and interest from shares, and not only to salaries, it provides greater equity than payroll taxes.

The second measure is the setting, in 1996 of a kind of public expenses cap. Since then, the French Parliament vote an annual national health insurance spending objective (Objectif National de Dépenses de l'Assurance maladie ONDAM). It sets an annual target, a financial limit on health insurance expenditure by the NHI. This objective is based on expert reports and assessed by the National Audit Office (Cour des Comptes). It is split in different sub-envelop by region and health care delivery sectors (Hospitals and ambulatory care) and settled for three years in advance.

However, the national target has never been reached or, when so, it was because the target was high enough not to put to heavy constraints on the actors. For instance, in the 2000 , the mean target was around $3 \%$ year while the GNP increased by only $1 \%$. To prevent too high extra expenses, a warning system has been implemented to correct the trend (actually, try to block) the expenses. As a whole this so-called objective is but an index of the NHI expenses; in the 2000's they continue to increase far beyond the GNP.

Whether successful or not, those two changes shifted the focus of the regulation from efficacy to efficiency. Those two changes open the door to more qualitative reforms involving more changes in the core of professional practices.

\section{The early XXIth century: breaking the walls}

Main reforms occurring at the beginning of the XXI century show that, on the one hand, the health care delivery system is on its way to open frontiers (whether internal or external) and, on the other hand, that rationalization is about to found its way through the rising power of new actors. In effect, since the 2000's, most of the main changes are grounded on a kind of New Public Management giving to new Agencies the main role between the State, the health care Professionals and the citizens. Meanwhile, experts (either economists, managers or scientist) have seen their decision power improved.

The goal is no more to accompany the growth of the health care supply but to optimize the resources allocated to public health. This need a stronger Administration, the aim of which is mainly to fight against physician's autonomy while trying to associate them to the reforms. This tension, if not contradiction, is the main aspect of the French dynamic steering, or better, muddling through ${ }^{(7,8)}$ from a Bismarck to Beveridge like model.

To illustrate this shifting paradigm, some examples will be taken in four different spheres of the regulation. The first one in the field of institutions, the second in the field of universal coverage, the third one is focused on physicians autonomy and the last one is about the rising of a new division of labor. 


\section{Changing the institutional context}

The first reform was, in April 2010, the creation of the Regional Health Agencies (ARS) in order to gather in a one and stronger body, four existing institutions: the Agences Régionales d'Hospitalisation (ARH), the Departmental Directorates for Health and Social Affairs (DDASS), the DRASS and the regional healthcare insurance funds. At the time when the ARHs were created (in 1996), there was some question as to whether it was intended to serve centralising or decentralising purposes. Some people felt that the creation of the ARHs was an attempt by the French State to regain control of hospital, whose efficiency and fairness needed to be improved. The main issues was to reorganise the highly segmented internal structure of public hospitals while trying to open them to their environment (ambulatory medicine and social care). The goal was to avoid local competition inside and amid hospitals giving incentives for the hospital to contract.

Actually, since the 1990s, contracting has been one of the main strategies used to improve the resource allocation process. The contracts are based on a five-year hospital project that has to fit into the negotiated regional plan (SROS). The theoretical aims of these contracts are to avoid transaction costs and to fill the information gap between the health insurance system and state agencies on the one hand and individual hospitals, on the other hand.

In this context, shifting from ARH to ARS has a stronger meaning. Actually, the main outcome of the ARS is that, from now on, the contracting as well as the planning include not only Hospitals management and regulation but, potentially, the ambulatory care as well as, to some extent the social sector.

\section{Looking for an already existing Universal Coverage}

The second reform is a last move toward universal coverage. Indeed, as seen, the $\mathrm{NHI}$ covers almost all French citizens. But, in 2000, the Couverture Médicale Universelle (CMU) introduce a third payment system without any copayment, for the poorest, facilitating access to care. Of course a kind of distribution process was existing since the implementation of a large $\mathrm{NHI}$, however, the $\mathrm{CMU}$ accentuated further this redistribution process. In effect, the CMU provides free complementary coverage, on a third party payer basis, for those whose income is less than around 600 euros a month. A basic package of goods and services defined a priori by law is linked to this specific insurance. This package includes ambulatory and hospital services as well as health services such as dentistry and optics, for which most patients are generally reimbursed at a lower rate, on the basis of a set price. The current CMU is not quite in line with the objectives initially announced ${ }^{(9)}$.

In fact, almost every French citizen already had the right to national health insurance coverage, which has always been mandatory. One might say that the egalitarian goal was achieved even before the CMU was introduced. To give the word universal greater reality, the socialist government therefore decided to introduce a third-party payment scheme. This affected not only the policy goals, but also the economic principles underlying the reform. The CMU shifted from an egalitarian approach (universal coverage) to a Rawlsian idea of public welfare (a completely free basic package for the poorest, as example) ${ }^{(5)}$. Then in, 2012, came the will to facilitate access not only to French citizens but, under some conditions to immigrants and strangers, under the name of Humanitarian State Medical Aid (AME). Some physicians were reluctant to take in charge those patients as they feared not to be paid back quickly by the State or the NHI. Thanks to a recent law, a physician cannot refuse to receive and help a CMU or an AME patient.

\section{Medicine based evidences}

The third one is the most important as it has long term impact on the internal rapport de force inside the system. Grounded on the rising Evidence Based Medicine, this move is but an attempt to control physician freedom of decision. In effect, as far as quality is concerned, French health professionals are highly skilled and qualified.

However, because internal segmentations are very strong, lifelong training is a much weaker point. An everlasting conflict between divided physicians organizations, the NHI, and the State has resulted in a situation where on the job training (formation continue) is impossible to set up. As a result, most new medical information is disseminated by pharmaceutical companies via scientific meetings and visits by sales representatives.

To improve this rather inefficient system, a first move towards evidence based medicine was initiated in early 1990's. But at this time, neither the professional nor the economic context was favorable and this attempt was a failure. It was mainly a move from contracts to constraints that first occurred through negotiations between the $\mathrm{NHI}$ and the physicians. This led to an agreement to restrict health care spending and its volume by introducing References Médicales Opposables that were a kind of guide lines. Those références were aiming at forbidding use of risky or costly medical procedures (such as no useful or dangerous examinations and clinical tests or prescriptions whose combined drugs should be not accurate). Physicians would have to pay fines when not following those references. 
As soon as the procedure was implemented, physicians felt they were controlled and punished. Therefore physicians Unions sued the State and won the trial. The whole process was abandoned, but this failure was a lesson for the decision makers: since then, medical experts, are strongly and constantly associated to the elaboration of evidence based rules other physicians are asked (not forced) to follow.

In 1997 a national Agency (the Agence Nationale d'Accréditation et d'Evaluation en Santé - ANAES) was created whose one of the task was to gather medical experts to define medical guidelines as well as implement assurance quality process for hospitals. These guidelines and quality assessments were quickly accepted by the majority of French physicians because they were written by peers and involve no direct incentives or penalties.

In 2004 the transformation of the ANAES in Haute Autorité de Santé (HAS) was a real turning point. Not only its field of action increased, but looking for efficiency was the main and explicit moto. The HAS is now seen as a NICE à la française and its soft power is not only real but increasing even if (or rather, because) its advices are not decisions or constraints but recommendations.

\section{Advanced practices}

The fourth change is about tasks transfer from physicians to other health professionals. This idea of qualified nurses replacing doctors is nothing new in the United States and, in France, it has first been tested experimentally on an exceptional basis at some pilot hospitals which volunteered for the job. Since the so-called Hôpital Patients Santé Territoires (HPST) Law, voted in July 2009, these practices have become widely recognized and may be adopted on a much larger scale in the future. For this purpose, projects focusing on the right to transfer duties will have to be authorized a priori by the ARS and assessed a posteriori by the HAS (Haute Autorité de Santé). These ongoing changes are bound to transform the relationships between healthcare professionals. A kind of formal recognition has already been applied through the so-called advanced practice nurses (pratiques infirmières avancées).

The American Nurses Association describes this practice as a main dynamic for the future: Advanced Practice Registered Nurses, whether they are nurse practitioners, clinical nurse specialists, nurse anaesthetists, or nurse midwives, play a pivotal role in the future of health care. APRNs are often primary care providers and are at the forefront of providing preventative care to the public ${ }^{(10)}$.

In France this move is imported on the basis of the Canadian model. On the one hand, it consists in giving to nurses more autonomy in order to cope the coming physician shortage and high costs. But the finality is broader as it is also a way to improve the today weak preventive medicine by involving professions that are not so attached to a fee for service payment and are willing (or used) to work as salaries.

This again is a Beveridgian characteristic. Furthermore, one can bet that this change is pushed by the feminisation of the physician professions and the fact that, today, a majority of medical students does not want to work on a solo practice but rather as employee of institutions.

That is why, starting in 2015, the ministry of health as well as local communities created incentives to implement Maisons de Santé Pluridisciplinaires (MSP). Gathering at the same place, physicians, nurses and sometimes pharmacist, those maisons are successful because they meet several needs for the physician to be less dependent of clients, for the population to have available health care

Those MSP were less than one hundred in 2010, they are now more than one thousand, mostly settled in rural or suburbs area.

Of course, according to the New Public Management à la française, the MSP are encouraged both by ARS and HAS because they are supposed to save cost while potentially focusing on prevention and health promotion. In the same perspective and to cope the growing number of chronic patients along with ageing population, a new profession is emerging under the name of care manager. Its mission is to help patients to found their way into the still segmented health care system and the administrative labyrinth.

All those changes have two main consequences. First, they weaken the historical leader role of both physicians and hospitals, second they demonstrate that it is possible to control costs while improving quality.

\section{CONCLUSION}

Because the main reforms are more driven by reaction and adaptation to external events than by the actual will of the actors, it is difficult to predict the future of the French Health Care System. Of course, some of the features are already there, such as an ageing population or the rising of e-medicine, these are actual challenges. But one can be optimistic as the feeling according to which the core of the $\mathrm{NHI}$ as to be protected is shared by every French citizen. 
For instance, not only the the patients out of pocket expenses is as low as $7 \%$ (countries average is around $20 \%$ ), but this percentage is stable despite numerous political changes. Furthermore, it is thanks to national or regional agencies (gathering experts, managers, health care professionals and policy makers) that the system is improving in terms of efficacy. Actually, preserving initial values is a line every policy makers kept for years and will continue to keep.

Of course some opposite moves can be seen and some structural problems, such as inequalities, are still to be fight. That is the reason why, as for today, the French health care system is highly administered. As in most European countries, this is a guarantee against potential (but actually shy) attempts of private for profit bodies to enter the health care market. Whether Bismarkian or Beveridgian we know that the room left to private actors has to be small. The French experience allows to add one point: not only the noble goal of extensive Universal Coverage can be reached without introducing private for profit actors in the insurance field but, even more, such a policy will make this goal much more difficult to reach. The main reason is that the market logic is shortsighted, while public health needs continuity and long term policies. Since the last presidential election, the United States example gives to the whole world the example not to be followed.

Therefore, what has been written about Latin America health care Systems' future is quite in line with the French experiences: Although economic crises test the resilience of health systems and the resolve of political leaderships, they also create unique opportunities. Leadership matters most in times of crisis by accelerating economic and social reforms to further reduce socioeconomic disparities and make universal health coverage a reality for all.

\title{
ACKNOWLEDGMENTS
}

The author warmly thanks Juliana Braga de Paula for her help and incentives in writing this article. This article is inspired by a lecture given at the International Forum of Universal Health Systems, Fortaleza in March 2017.

The author thanks Medical Union, organizers of this international Forum as well as the participants and specially, the members of the panel innovation and resilience.

\section{REFERENCES}

1. Knight B. From welfare state to welfare society [Internet]. 2002 [accessed on 2018 Jan 02]. Available from: https:// www.rethinkingpoverty.org.uk/download/publications_\&_reports/Beveridge-supplement_WEB_SPREADS.pdf

2. Hall P, Soskice D. Varieties of capitalism: the institutional foundations of comparative advantage. Oxford: Oxford University Press; 2003.

3. Esping-Andersen G. The social foundations of postindustrial economies. Oxford: Oxford University Press; 1999.

4. Mossé P. Bismarck et Beveridge: des protoptypes aux archétypes. Après Demain. 2017(42):12-4.

5. Bellanger M, Mossé $P$. The search for the holy Grail: combining decentralised planning and contracting mechanisms in the French health care system. Health Econ. 2005;14(Suppl 1):S119-32.

6. LaBelle R, Stoddart G, Rice T. A re-examination of the meaning and importance of supplier-induced demand.J Health Econ. 1994;13(3):347-68.

7. Lindblom CE. The science of "muddling through". Public Admin Review. 1959;19(2):79-88.

8. Lindblom CE. Still muddling, not yet through. Public Admin Review. 1979;39(6):517-26.

9. Nay $\mathrm{O}$, Béjean $\mathrm{S}$, Benamouzig $\mathrm{D}$, Bergeron $\mathrm{H}$, Castel $\mathrm{P}$, Ventelou $\mathrm{B}$. Achieving universal health coverage in France: policy reforms and the challenge of inequalities. Lancet. 2016;387(10034):2236-49.

10. American Nurses Foundation. Advanced Practice Registered Nurse (APRN). 2016 [accessed on 2018 Jan 02]. Available from: http://www.nursingworld.org/EspeciallyForYou/AdvancedPracticeNurses.

\author{
Mailling address: \\ Philippe Mossé \\ Lest-Amu-Cnrs, Aix-en-Provence \\ 35 Av. J. Ferry - 13626 - Aix en Provence \\ Marseille - France \\ E-mail:philippe.mosse@univ-amu.fr
}

